Leercoaching in het hbo

Leercoach 


\section{Leercoaching in het hbo}

Een kapstok om studenten uit te dagen zelf de regie te nemen

Jette van der Hoeven 2e druk

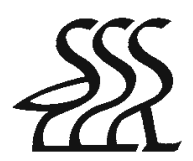

Bohn Stafleu van Loghum

Houten 2009 
(C) 2009 Bohn Stafleu van Loghum, onderdeel van Springer Uitgeverij Alle rechten voorbehouden. Niets uit deze uitgave mag worden verveelvoudigd, opgeslagen in een geautomatiseerd gegevensbestand, of openbaar gemaakt, in enige vorm of op enige wijze, hetzij elektronisch, mechanisch, door fotokopieën of opnamen, hetzij op enige andere manier, zonder voorafgaande schriftelijke toestemming van de uitgever.

Voor zover het maken van kopieën uit deze uitgave is toegestaan op grond van artikel I6b Auteurswet $19 \mathrm{I} 2 \mathrm{j}^{\circ}$ het Besluit van 20 juni 1974 , Stb. 35I, zoals gewijzigd bij het Besluit van 23 augustus 1985 , Stb. 47I en artikel 17 Auteurswet I9I2, dient men de daarvoor wettelijk verschuldigde vergoedingen te voldoen aan de Stichting Reprorecht (Postbus 305I, 2130 KB Hoofddorp). Voor het overnemen van (een) gedeelte(n) uit deze uitgave in bloemlezingen, readers en andere compilatiewerken (artikel I6 Auteurswet I9I2) dient men zich tot de uitgever te wenden.

Samensteller(s) en uitgever zijn zich volledig bewust van hun taak een betrouwbare uitgave te verzorgen. Niettemin kunnen zij geen aansprakelijkheid aanvaarden voor drukfouten en andere onjuistheden die eventueel in deze uitgave voorkomen.

Bohn Stafleu van Loghum

Houten 2009

ISBN 9789031353132

NUR 84I

Ontwerp omslag en binnenwerk: Studio Bassa, Culemborg Automatische opmaak: Pre Press, Zeist

Ie druk 2007

2e druk 2009

Bohn Stafleu van Loghum

Het Spoor 2

Postbus 246

3990 GA Houten

www.bsl.nl 


\section{Inhoud}

Woord vooraf

I Inleiding I I

I.I Wat is leercoaching? I I

I.2 Voor wie is leercoaching? I 3

I. 3 Wie is de leercoach? I5

I.4 Wat doet de leercoach? I7

I.5 Overzicht van de hoofdstukken I 8

I.6 Leercoaching in gebruik 20

I.7 Opdrachten Basiswerkwijze leercoaching 2 I

I.8 Leercoaching en het maken van de leer-

I.8.I Wat is de leercoachlijn? 28

I.8.2 Inzetten opdrachten 29

I.8.3 Plaatsen opdrachten 29

I.9 Opdrachten bij het maken van de leer-
coachlijn

2 Leren $\quad 39$

2.I Inleiding 39

2.2 Leercoachgroepen en kwadrant 40

2.3 Leren door reflecteren 44

2.4 Opdrachten leren 46

3 Leercoachen 50

3.I Inleiding 50

3.I.I Waarom leercoachen? $5 \mathrm{I}$

3.I.2 Hoe leercoachen? $5 \mathrm{I}$

3.2 Leercoachen door de leercoach in het hbo $5 \mathrm{I}$

3.3 Leercoachende houding student 52

3.5 Opdrachten leercoachen $\quad 55$ 
$4 \quad$ Kwadrant $\quad 58$

4.I Inleiding 59

4.2 Opdrachten vanuit het kwadrantmodel 60

4.2.I Opdrachten bij het kwadrant kunnen 6 I

4.2.2 Opdrachten bij het kwadrant willen 69

4.2.3 Opdrachten bij het kwadrant doen 79

4.2.4 Opdrachten bij het kwadrant presteren I03

4.3 Didactische aanwijzingen voor de leercoach I I 4

4.3.I Didactische principes om leercoaching te begeleiden

I I 4

4.3.2 STAR-methode I I 6

4.3.3 STAR-gesprekstechnieken I I 8

4.3.4 Principes om met leercoaching onderwijs te ontwerpen

5 Leercyclus $\quad$ I 24

5.I Inleiding I 24

5.2 De leercyclus en het kwadrant I 25

5.3 Opdrachten leercyclus $\quad$ I 27

5.4 Didactische aanwijzingen voor de leercoach I 36

5.4.I Principes om leercoaching te gebruiken I 36

5.4.2 Principes om met leercoaching onderwijs te ontwerpen

6 Samenwerken $\quad$ I 40

6.I Inleiding I 40

6.2 Samenwerkend leren I 4 I

6.3 Vaardigheden om samen te werken I 42

6.4 Opdrachten samenwerkend leren I 43

6.5 Didactische aanwijzingen voor de leercoach I 53

6.5.I Principes om leercoaching te gebruiken I 53

6.5.2 Principes om met leercoaching onderwijs te ontwerpen

$7 \quad$ Zelfstandig werken en zelfstandig leren $\quad$ I 58

7.I Inleiding I 58

7.2 Leerstijlen en leren I59

7.3 Opdrachten zelfstandig leren I 62

7.4 Didactische aanwijzingen voor de leercoach $\quad$ I78

7.4.I Principes om leercoaching te gebruiken I78

7.4.2 De vier leercoachstijlen I 8 I

7.4.3 Werkvorm ontwikkel situationeel leer-
coachen 
7.4.4 Principes om met leercoaching onderwijs te ontwerpen

I 85

$8 \quad$ In vijf stappen competent $\quad$ I 94

8.I Inleiding I 94

8.2 Kenmerken van een competente student/ leercoach $\quad$ I 95

8.3 Het stappenplan I 96

8.4 Opdrachten In vijf stappen competent $\quad$ I 97

8.5 Didactische aanwijzingen voor de leercoach 206

Bronnen \& Literatuur $\quad 208$ 


\section{Woord vooraf}

doen wat werkt gebaseerd op wetenschap

expliciet verwachtingen uitspreken

wetenschap voeden

samen kennis delen en

vermeerderen

werk en leer slim

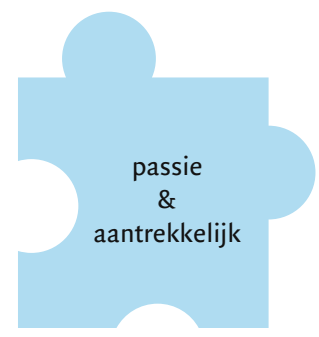

Puzzel je mee?

Zie hoofdstuk 8.
Mijn missie: doen wat werkt gebaseerd op wetenschap. Onderwijskunde is een jonge wetenschap. Laten we met zijn allen de juiste dingen doen zodat onderwijs op een hoger plan komt. Voor mij betekent dat, dat wij:

- expliciet verwachtingen uitspreken en gedrag positief bekrachtigen;

- de onderwijskundige theorieën inzetten zoals deze zijn bedoeld, dus geen theezakjesmodel;

- wetenschappers voeding geven zodat zij ervaringen vanuit de praktijk wetenschappelijk kunnen onderzoeken;

- vervolgens iets doen met de uitkomsten van onderzoek;

- zelf methodisch werken en dingen doen vanuit de juiste reden;

- de krachten van de praktijk en theorie bundelen;

- vooral samen kennis delen en vermeerderen.

Voor mijn gevoel zorgen wij er op deze manier voor dat wij model staan voor studenten. Door regie te nemen over wat wij doen en dat expliciet uit te dragen zorgen wij voor onze studenten. Werk en leer slim.

Je kunt slim zijn. Maar je moet dat wel willen. Uit onderzoek (Harrison \& Kessels) blijkt dat je kennis groter wordt als je je richt op wat je zelf wilt weten, als je duidelijk kijkt naar de problemen die je tegenkomt, hierop reflecteert en je laat leiden door je eigen planning.

Als het je lukt om dit te doen vanuit je eigen passie, vanuit een netwerk waarin je je goed voelt en je kunt communiceren over de toename van je kennis, dan zorg je er zelf voor dat je met plezier je werkzaamheden kunt uitvoeren vanuit passie en wederzijdse aantrekkelijkheid.

Hoe kunnen we nu in het hbo een leeromgeving creëren die dit mogelijk maakt? Het gaat dan in eerste instantie om een werkwijze voor leercoaches en studenten om bovenstaande kenmerken te 
ontwikkelen. Vervolgens worden studenten voorbereid op 'een leven lang leren', zodat zij blijven leren en zich ontwikkelen tot een kenniswerker. Een kenniswerker zie ik hier als een persoon die continue in gesprek met anderen zijn eigen kennis toetst en verspreidt. Juist door het delen van kennis ontstaan er mogelijk nieuwe en innovatieve ideeën. In het hbo is dat van belang, zodat er bijvoorbeeld dwarsverbanden ontstaan tussen:

- de opleiding en de praktijk;

- de vakdocent techniek en de onderwijskundig medewerker;

- vakgebieden onderling, zodat transfer mogelijk is.

Daarnaast is het van belang dat deze dwarsverbanden structureel een plaats krijgen in het leerplan van de opleiding. In de te maken leercoachlijn worden proces en vakinhoud met elkaar verweven. Vanuit afspraken die met betrokken partijen worden gemaakt is helder waar de opleiding voor staat in de opbouw van zelfstandig leren van zijn studenten.

Dit boek gaat over leercoaching; een leerconcept als kapstok die tot doel heeft het bovenstaande te concretiseren in de school in samenwerking met de praktijk. Door een goede samenwerking tussen theorie en praktijk is het mogelijk om de hbo-opleiding van de student in te richten die aansluit op de betrokken partijen. Studenten worden uitgenodigd de eigen drijfveren te ontdekken/benoemen. Vanuit deze drijfveren kunnen zij zich ontwikkelen tot kenniswerkers binnen de kenniseconomie.

Leercoaching krijgt in eerste instantie vorm door middel van samenwerkend leren en vanuit de invalshoeken:

- Wat wil de student? Wat wil ik?

- Wat kan de student? Wat kan ik?

- Wat doet de student? Wat doe ik?

- Wat presteert de student? Wat presteer ik?

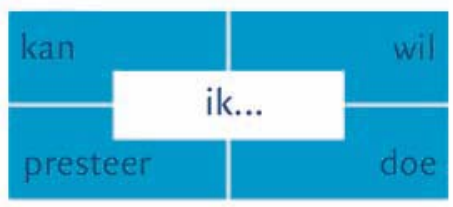

De inzichten die deze benadering met zich meebrengt, maken het mogelijk de student meer handvatten te bieden om naar zichzelf te dwarsverbanden structureel maken

leercoachlijn: vakinhoud + proces koppelen

uitnodiging tot werken vanuit drijfveren

samenwerkend leren 
bewegen, verbinden en resultaat behalen

kennis delen en vermeerderen kunnen kijken op een manier zoals verwacht wordt van een gediplomeerde beroepsbeoefenaar.

leercoaching in ontwikkeling

Vanaf 2000 is leercoaching in ontwikkeling binnen de opleiding tot verpleegkundige niveau 4 van het Albeda College te Rotterdam. Verpleegkundigen in opleiding geven aan dat zij door middel van leercoaching een voorsprong hebben op anderen in het omgaan met elkaar, het samenwerken en het zelfstandig oppakken van leren. Vanaf 2004 is leercoaching in ontwikkeling binnen het hoger beroepsonderwijs. Studenten en leercoaches geven het belang aan van een structurele opbouw in het samenwerkend en zelfstandig leren. Bij deze wil ik onder andere Peter Verberkt bedanken voor zijn enthousiaste inzet bij het tegenlezen van leercoaching en Lodewijk Kaanders voor zijn enthousiaste inzet. $\mathrm{Zij}$ hebben ruime ervaring in het begeleiden van hbo-studenten. De vele hbo-studenten (onder andere Wim Kamerling, Wilma Kreffer en Geerte van der Zee) wil ik bedanken voor hun bijdrage aan dit boek door middel van hun ervaringen.

In het bijzonder wil ik Richard Troost bedanken voor de discussies die wij steeds hebben over hoe je bewegen, verbinden en resultaat kunt behalen vanuit de juiste reden. Deze lijfspreuk van hem betekent: terugdringen van de bureaucratie; het geld terug naar het primaire proces; en dat docenten gezamenlijk de regie over hun eigen onderwijs krijgen.

Zowel de student als de docent zijn het hart van een opleiding. Zij gebruiken beiden alle hulpmiddelen uit leercoaching. Deze hulpmiddelen dragen bij tot het ontstaan van aantrekkelijke communicatie waarin zij vanuit gelijkwaardigheid het leerproces oppakken. Zowel van elkaar als van zichzelf met als doel dat zij kennis delen en vermeerderen.

Rotterdam, januari 2009

Jette van der Hoeven ${ }^{\mathrm{I}}$

I De auteur wil graag blijven leren en ontwikkelen en daarbij gebruikmaken van aanwijzingen van gebruikers. In leercoaching zijn wetenschappelijke uitgangspunten verwerkt. Gezocht is naar een concrete invulling van deze uitgangspunten. Bij deze de uitnodiging om reacties te mailen naar info@onderwijsontwikkeling.nl. 